$\xi^{2}=-1$

\title{
Application of airborne radiometric method in geologic mapping of Malufashi area and Environs, Northwestern Nigeria
}

\author{
Ibe, Stephen Onyejiuwaka ${ }^{1 *}$, Nwokeabia, Charity Nkiru ${ }^{2}$ \\ ${ }^{1}$ Department of Physics, Federal University Otuoke, Bayelsa State, Nigeria \\ ${ }^{2}$ Department of Geophysics, Nnamdi Azikiwe University Awka, Anambra State, Nigeria \\ *Corresponding author E-mail: stphnibe@yahoo.com
}

\begin{abstract}
In this study, the airborne radiometric data over Masufashi Area of Katsina State and Environs, Northwestern Nigeria were acquired, processed and gridded to generate the concentration maps of percentage Potassium, equivalent Thorium and equivalent Uranium in order to carry out the geologic mapping of the area. Additionally, the abundance ratios, $\mathrm{U} / \mathrm{Th}, \mathrm{U} / \mathrm{K}$ and $\mathrm{Th} / \mathrm{K}$ and the ternary images of the three radioactive elements were produced. The images obtained from the radiometric data showed that the study area comprises five major rock types, based on their variation in the concentration of the three radioactive elements. The actual extent, boundary and distribution of the rock units within the study area were defined; hydrothermal alteration zones were mapped. The altered zones were noted to be associated with mineralization in the quartzite rich schist formation. The interpretation also proved valuable in demarcating some rock types with different properties. The delineated geology and hydrothermally altered zones led to the identification of nine zones with the potentials of gold mineralization. The delineated structures aided the design of the geologic map of the study area. This research showed the value added by airborne geophysics in geologic mapping and recommends the analysis of airborne data as a major phase during reconnaissance survey, prior to geologic mapping.
\end{abstract}

Keywords: Aeroradiometric; Geologic Mapping; Hydrothermal Alteration; Quartzite Rich Schist; Gold Mineralization.

\section{Introduction}

Airborne radiometric survey involves flying a light aircraft with a gamma ray spectrometer mounted on it to measure gamma rays that originate from radioactive elements within $30 \mathrm{~cm}$ to $40 \mathrm{~cm}$ of the top soil. Notwithstanding the shallow depth from which the radiations are emitted, the radioactive element contents of the bedrock are reflected in the composition of the superficial radioactive elements (Urquhart, 2013). The distribution of radioactive elements relates to the differences in lithology of common rocks and alteration or metamophism processes. The gamma rays measured are characteristic of the radioactive elements from which they are emitted in the subsurface. Though, there are many naturally occurring radioactive isotopes or elements, majority of them are rare or possess very weak radioactivity. Only a limited number of isotopes of the natural elements emit gamma rays; and among these, there are only three which are common enough within earth materials to make them geologically useful (Urquhart, 2013). These three are $\mathrm{Bi}^{214}, \mathrm{Tl}^{208}$ and $\mathrm{K}^{40}$. The isotope, $\mathrm{Bi}^{214}$, comes from the decay of $\mathrm{U}^{238}$ and is, therefore, an indication of the concentration of uranium in the earth materials that lie within the range of the detector. $\mathrm{Tl}^{208}$ comes from the decay of $\mathrm{Th}^{232}$ and is an indicator of thorium content; and $\mathrm{K}^{40}$ is one of the minor natural isotopes of potassium and the only isotope of $\mathrm{K}$ that is radioactive. It makes up only $0.012 \%$ of the total potassium in rocks and soils, but because this fraction remains quite constant, even during weathering and metamorphism, the gamma radiation from it is a good indicator of changes in the amount of potassium in rocks (Urquhart, 2013). Therefore, the radioactive elements of principal interest in radiometric survey are uranium $\left({ }_{92}^{238} \mathrm{U}\right)$, thorium $\left({ }_{90}^{232} \mathrm{Th}\right)$ and potassium $\left({ }_{19}^{40} \mathrm{~K}\right)$. Hence, the distribution of radioactive elements such as Potassium $(\mathrm{K})$, Thorium (Th) and Uranium (U) concentration in soil and rocks relate to the differences in lithology of common rocks, alteration and metamorphism processes (Dickson and Scott, 1997; Brempong et al. 2019). The concentration of these radioactive elements is therefore used in geologic mapping, as different rock types can be recognized from their distinctive radioactive signatures (Moxham, 1963). Potassium/Thorium $(\mathrm{K} / \mathrm{Th})$ and Uranium/Thorium (U/Th) variations are important indicators of alteration zones (Airo, 2002); these alteration zones are favourable zones for mineralization and should be looked for in exploration.

Over the years, some locations within Masufashi Area of Katsina State and Environs, Northwestern Nigeria, have attracted the attention of the geosciences community in Nigeria owing to the presence of kimberlite in the area (Onugba, 1979). Also the area is known for the occurrences of gold.

Nigeria's economy predominantly depends on the price of crude oil in the world market. In recent years there has been sharp decline in the price of crude oil and it is expected to decline further owing to the world's treaties against sources of greenhouse gases; fossil fuel usages contribute the gases significantly to the atmosphere. A sharp decline is expected in the oil price when most countries in the world use Electric Motors in preference to the motors powered by fossil fuel. Hence, there is need for Nigeria to diversify her sources of in- 
come instead of overdependence on crude oil. One of the ways this can be achieved is to embark on the exploration of the minerals the country is endowed with. There is need to delineate hydrothermally altered zones with the potentials of mineralization. The search for structures favourable for mineralization in the area is a right path towards liberating Nigeria's economy from overdependence on crude oil.

There is no meaningful exploration in a place without the knowledge of the geology of the area. There is no detailed information on the geological mapping of the study area. Information on the regional geology of the area is based on the low resolution aero-surveys carried out in Nigeria in 1970s and on ground surveys conducted at isolated locations of interest. These information lack details on the alteration zones within the study area. Also, the lithological boundaries based on those surveys were estimated in designing the geology map of the area. This study applied high resolution airborne radiometric data, in the geological mapping of the study area, with the aim to define the lithology, boundary and distribution of the rock types and delineate the alteration zones favourable for mineralization within the place. This offered a high resolution evaluation of the study area as compared to the ground geologic mapping which was done at low resolution and at isolated locations. The study area is characterised with outcrops and according to Silva et al. (2003) radiometric method is excellent tool in mapping and tracing of individual lithological units in areas of outcrop.

\section{Location and geologic settings of the study area}

The study area lies between Latitudes $11^{\circ} 28^{\prime} 00^{\prime \prime} \mathrm{N}$ and $11^{\circ} 44^{\prime} 00^{\prime \prime} \mathrm{N}$ and Longitudes $07^{\circ} 30^{\prime} 00^{\prime \prime} \mathrm{E}$ and $08^{\circ} 00^{\prime} 00^{\prime \prime} \mathrm{E}$ respectively. It covers Malufashi Local Government Area of Katsina State and its environs, Northwestern Nigeria. The area is located on a plateau at a height of about $670 \mathrm{~m}$ above sea level and more than $640 \mathrm{~km}$ away from the sea (Hore, 1970). The area is located within the sparsely populated Guinea Savannah. It has a typical savannah climate of distinct wet and dry seasons, with a moderate rainfall of about $1047 \mathrm{~mm} / \mathrm{a}(\mathrm{Garba}$ and Schoeneich, 2003). The Rainy season usually starts in May and ends in October and the Dry season lasts from late October to April. The study area falls within the Pre-Cambrian Basement Complex of Northern Nigeria. The Nigerian basement complex forms a part of the Pan-African mobile belt and lies between the West African and Congo Cratons and south of the Tuareg Shield (Black, 1980). The basement occupies the reactivated region which resulted from plate collision between the passive continental margin of the West African Craton and the active Pharusian continental margin (Burke and Dewey, 1972; Dada, 2006). The basement rocks are believed to be the results of at least four major Orogenic cycles of deformation, metamorphism and remobilization corresponding to the Liberian $(2,700$ $\mathrm{Ma})$, the Eburnean (2,000 Ma), the Kibaran (1,100 Ma), and the Pan-African cycles (600 Ma). The first three cycles were characterized by intense deformation and isoclinal folding accompanied by regional metamorphism, which was further followed by extensive migmatization. The Pan-African deformation was accompanied by a regional metamorphism, migmatization and extensive granitization and gneissification which produced syntectonic granites and homogeneous gneisses (Abaa, 1983). Late tectonic emplacement of granites and granodiorites and associated contact metamorphism accompanied the end stages of this last deformation. The end of the Orogeny was marked by faulting and fracturing (Gandu et al. 1986; Olayinka, 1992). According to Rahaman (1988), the major rock types within the study area include Migmatitic gneiss, granite and schist, into which has been an emplacement of granite and, to a lesser extent, more basic materials. Figure 1 shows the geology map of the study area. Ibe et al. (2012) and Ibe (2016) observed that the bedrocks in the study area are made up of rocks of different lithology, separated by elongated rock contact and fault zones.

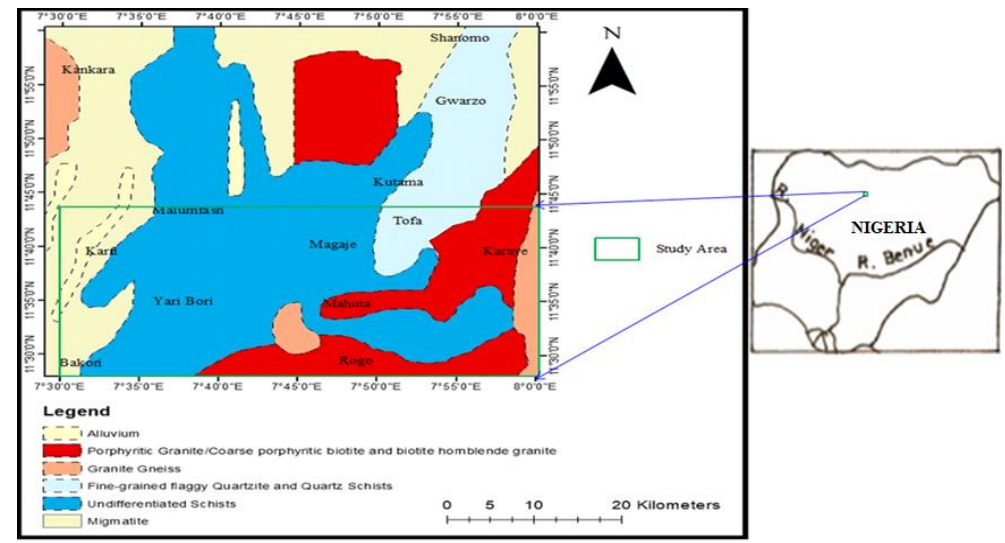

Fig. 1: Geology Map of the Study Area.

\section{Materials and methods}

The airborne radiometric dataset used for this study is from the high-resolution airborne radiometric survey coverage in Nigeria in 2009 carried out by Fugro Airborne Survey along a series of NW - SE flight lines at $500 \mathrm{~m}$ spacing, $20 \mathrm{~km}$ tie lines spacing and at $100 \mathrm{~m}$ terrain clearance. The data were acquired from the Nigerian Geological Survey Agency. The parameters measured were the radiations emitted from Potassium (K) in \%, Uranium (U) and Thorium (Th) in ppm. In order to recognize and understand radiometric signatures associated with the host rocks important to mineralization, enhancing techniques such as composite images, ratio maps, as well as potassium $(\% \mathrm{~K})$, equivalent thorium (eTh $\mathrm{ppm})$ and equivalent uranium (eU ppm) maps were generated. The terms "equivalent uranium" and "equivalent thorium" mean the amounts of these two elements that are implied by the $\mathrm{Bi}^{214}$ and $\mathrm{Tl}^{208}$ gamma radiation if equilibrium is assumed (Urquhart, 2013). The three radioactive elements' grids were generated using a minimum curvature algorithm at grid cell size of $100 \mathrm{~m}$. In this study, at the preliminary data processing stage using Geosoft (Oasis Montaj, version 8.4) software, the data were microlevelled for the removal of residual errors and noise. The software was used also for the gridding of the dataset of $\% \mathrm{~K}, \mathrm{eTh}(\mathrm{ppm})$ and $\mathrm{eU}$ $(\mathrm{ppm})$ and for the production of their respective maps, the ratio maps and the ternary images. Arc GIS software was used for map integration and digitization of interpreted lithology and structures.

The gridded images were used to interpret and map the geology of the area, making inferences to literature what high and low radiation anomalies imply in relation to the geology at various locations within the study area. The generated ratio maps and ternary images of the three radioactive elements also enhanced the delineation and mapping of zones that are hydrothermally altered. A decrease in Th with an 
increase in $\mathrm{K}$ is indicative of alteration environments in an ore deposit (Ostrovskiy, 1975). A low uranium concentration with a high potassium concentration is indicative of the presence of granitoid rocks. In this study the ternary map was created with the grid displayed in Geosoft by assigning potassium with red colour, thorium with green colour and uranium with blue colour. The ternary map showed the concentration of the elements relative to one another.

Potassium is normally added to host rocks by mineralizing hydrothermal solutions; it is therefore the most reliable pathfinder in airborne gamma ray surveys in locating hydrothermal ore deposits, especially gold deposits (Hoover and Pierce, 1990). Minerals such as Kfeldspar and muscovite are normally the sources of $\mathrm{K}$ in rocks that are hydrothermally altered, and these minerals can be detected by a rise in $\mathrm{K}$ counts. Rocks that are free of these minerals have very low K-activity. Thus, $\mathrm{K}$ activity is very low in all mafic and ultramafic rocks (Manu, 1993). Potassium concentrations generally increased with increasing weathering processes (Takyi-Kyeremeh et al. 2019). The concentration of potassium is a key factor in the identification of geologic units that are affected by hydrothermal systems favourable for the development of mineralization.

Weathering and metamorphism can modify the radioelement content of rocks profoundly (Urquhart 2013). Uranium is easily oxidized to a water-soluble form; and can be readily leached from pegmatites and granites and redeposited in sediments at large distances from the source rock. Thorium has no soluble ion and therefore tends to remain with the parent rock or is transported over relatively short distances in the form of solid mineral grains. Common thorium-bearing minerals such as zircon and monazite are heavy and thus accumulate in placers and in the heavy mineral fraction of clastic sediments (Urquhart 2013).

\section{Results}

Figure $2 \mathrm{~A}$ is the $\% \mathrm{~K}$ concentration map of the study area and it shows $\mathrm{Hp} 1, \mathrm{Hp} 2$, and $\mathrm{Mp} 1$ as regions of very high, high and moderate $\mathrm{K}$ concentrations respectively, while Lp1, Lp2, Lp3 and Lp4 are regions of low K concentration in the area. Figure 2B is the eTh concentration grid for the study area and it shows Hp1a and Hp1 as sub-regions of Hp1 (Fig. 2A) which have very high and moderate to low Th count respectively. Similarly, the uranium concentration grid for the study area (Fig. 2C) shows Hp1a and Hp1b as sub-regions of Hp1 which have very high and moderate uranium counts respectively. Also, Figs. 2B and 2C show Mp1a and Mp1b as sub-regions of Mp1 (Fig. 2A) which have moderate to low and high Th counts (Fig. 2B) respectively and low and high U counts (Fig. 2C) respectively. Hp2 and Lp2 regions have high to moderate and moderate to low Th count (Fig. 2B) respectively; they have high and low U count (Fig. 2C) respectively. The regions, Lp1, Lp3 and Lp4, each has low Th activity in Fig. 2B and in Fig. 2C, Lp1 has low to moderate U count while Lp3 and Lp4 each has low U activity.
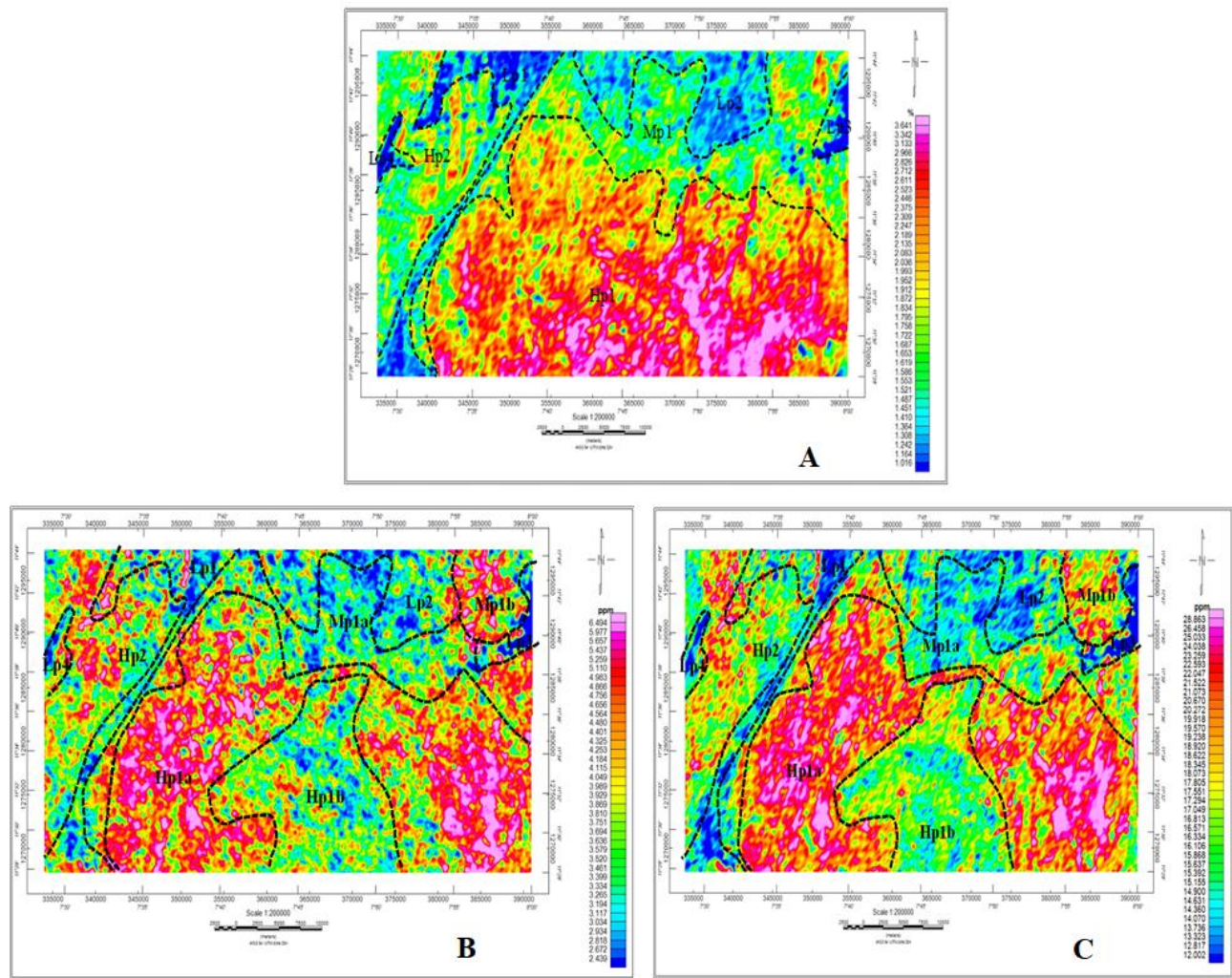

Fig. 2: Map of (A) Potassium (K), (B) Thorium (eTh) and (C) Uranium (eU) Concentration in the Study Area.

\subsection{The abundance ratios, $\mathrm{K} / \mathrm{Th}, \mathrm{U} / \mathrm{Th}, \mathrm{U} / \mathrm{K}$, and the ternary map of the study area}

The abundance ratios, $\mathrm{U} / \mathrm{Th}, \mathrm{U} / \mathrm{K}$ and $\mathrm{Th} / \mathrm{K}$, are often more diagnostic of changes in rock types, alteration, or depositional environment than the values of the radio-isotope abundances themselves, which are subject to wide variations due to soil cover (Urquhart, 2013). Thus, profiles that include these ratios are often very useful for picking specific target anomalies for ground follow-up. Figures $3 \mathrm{~A}$ - C respectively represent potassium-thorium (K-eTh), Uranium-Thorium (eU-eTh) and Uranium-Potassium (eU-K) ratio maps for the study area and Fig. 3D is the ternary map of all the three radioactive elements in the area. 

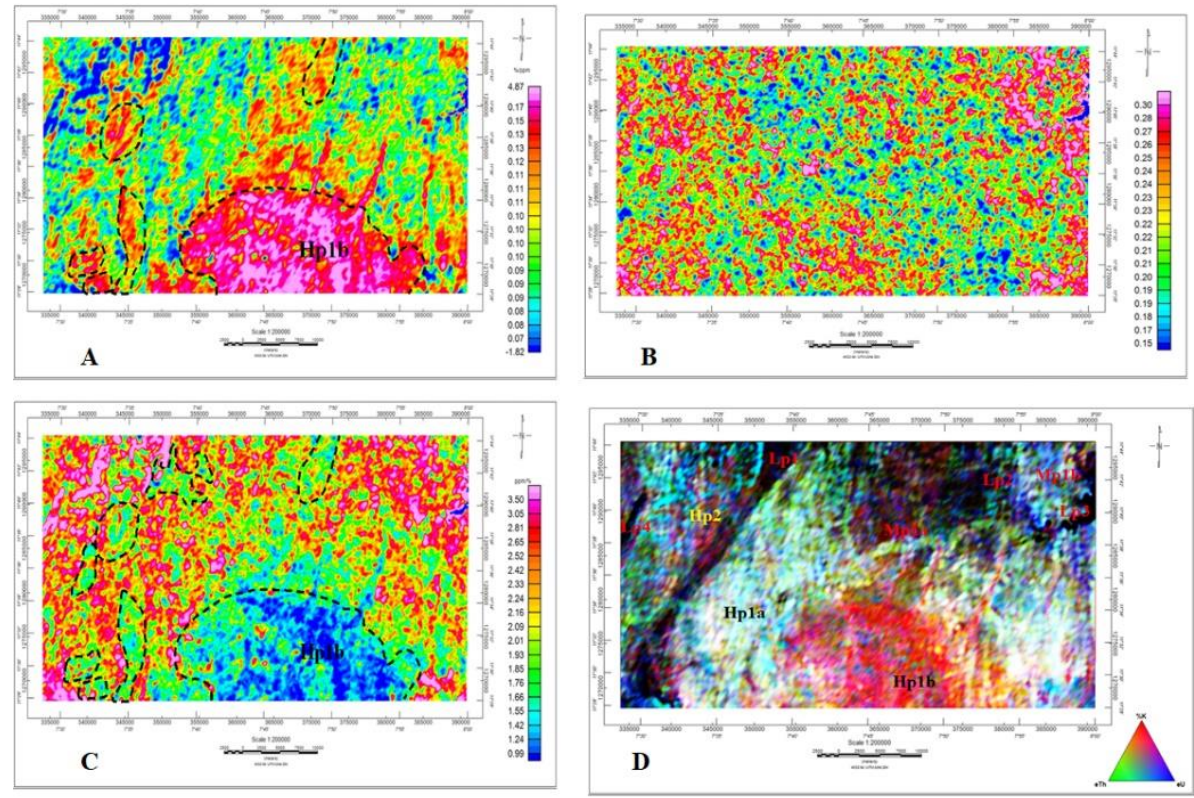

Fig. 3: Map of Abundance Ratios for (A) Potassium - Thorium (K/eTh), (B) Uranium - Thorium (eU/eTh), (C) Uranium - Potassium (eU/K) and (D) Ternary Images of \% K, eTh and eU in the Study Area.

\section{Discussion}

Figure 2A shows very high potassium concentration at $\mathrm{Hp} 1$ region. This suggests the presence of porphyritic granite in the region, since granite normally contains high potassium activity minerals (ICRU, 1994). Figures 2B and 2C show that unlike in Fig. 2A, Hp1 region is made up of two sub-regions (Hp1a and Hplb) of significant differences in Th and U activities respectively. Hp1a rock is characterised by high potassium and thorium concentrations suggests that the body is most likely schist rock. In the uranium concentration map (Fig. 2C), Hpla has high uranium activity; this implies that there is high count of the three radioactive elements in the region. High concentration of all the three elements in the region indicates granitoid intrusive within the schist. Also, high concentrations of all the three radioactive elements are linked with thermal alteration of the schist rock and the presence of intrusive rocks within the schist. The metasedimentary formation of the schist also suggests that it (the schist) is most likely altered and could contain minerals such as pegmatite, quartz, and monzonite (Boadi et al. 2013). Hp1b is characterized by high potassium (Fig. 2A) and moderate to low concentration of thorium (Fig. 2B) and these suggest that the body is most likely porphyritic granite. These further suggest that Hp1 delineated as porphyritic granite owing to high potassium count, has two regions of schist (Hp1a) and porphyritic granite (Hp1b) respectively.

In Fig. 2A, Mp1 region which shows moderate potassium concentration is interpreted as being predominantly schist that has been intruded by igneous rock leading to an increase in $\mathrm{K}$ concentration. Figures $2 \mathrm{~B}$ and $2 \mathrm{C}$ show that unlike in Fig. $2 \mathrm{~A}$, Mp1 region is made up of two sub-regions, Mpla and Mplb, which have significant differences in eTh and eU concentrations respectively. The figures also show that unlike in Fig. 2A, there is no significant difference in the eTh and eU concentrations respectively at Mp1a and Lp2. This suggests that the two regions most likely have rock types of similar characteristics. They have moderate to low eTh count (Fig. 2B) and low to moderate K count (Fig. 2A) which suggest the presence of quartzo-feldspartic veins and quartzite rich schist rock (Boadi et al. 2013). Low eU concentration at Mp1a and Lp2 (Fig. 2C) is indicative of quartzite rich altered schist, while high eU concentration at Mp1b and Hp2 is indicative of gneiss rock. The most productive gold deposits are those found in quartz-pebble conglomerates (Boyle, 1979). Also, Boyle, (1979) observed that thorium and uranium accompany gold in the quartz-pebble conglomerate and in some skarn, vein and stockwork deposits in uraniferous areas. Most gold deposits containing the two radioactive elements are of Precambrian (Lower Proterozoic) age, although some epigenetic deposits of Paleozoic, Mesozoic and especially Tertiary age are uraniferous.

High K concentration region, $\mathrm{Hp} 2$, was delineated in the western part of the study area and indicates remobilization of $\mathrm{K}$ content in the rock unit. This suggests that the rock body of $\mathrm{Hp} 2$ is gneiss with origin of felsic igneous rock such as granite, rhyolite (quartz, felspar, and muscovite) and syenite. Hp2 has high to moderate eTh concentration (Fig. 2B) and high K concentration; this eTh counts is associated with minerals such as pegmatites, zircon, monazite, allanite, sphene apatite and xenotime, and these minerals are concentrated in metavolcanic rocks (Kearey et al. 2006). It then suggests that $\mathrm{Hp} 2$ is most likely migmatite gneiss and contains the listed minerals.

Lp1 and Lp2 are regions with low K concentrations in the study area and are found in the schist rocks. The Lp3 and Lp4 regions in the K map also reflect low eTh and eU concentrations respectively; the low concentration of all the three radioactive elements is characteristic of mafic to ultra-mafic volcanic rocks.

\subsection{Alteration zones within the study area}

The deductions from the ratio maps and the ternary images are complementary to those of the radio-isotope abundances. Potassium is more mobile than thorium; hence, K-eTh ratio anomalies are diagnostic of hydrothermal alterations which are characterized by K enrichment. Hansen (1980) and Wollenberg and Smith (1987) have presented the average values and ranges for radioelements' contents for rock varieties and Hoover et al. (1992) and Portnov (1987) stated that the ratio between K and eTh for unaltered rocks typically varies from $0.17 \% / \mathrm{ppm}$ to $0.2 \% / \mathrm{ppm}$. Rocks with K-eTh ratios remarkably outside this range have been named K or Th specialized (Portnov, 1987). Hence, the zones characterized by K-eTh ratio greater than $0.2 \% / \mathrm{ppm}$ values are the strong indicators of hydrothermal alterations. The areas affected by the hydrothermal process are indicated by pink colour and have high values, about $0.17 \% / \mathrm{ppm}$ to $4.874 \% / \mathrm{ppm}$, of K-eTh ratio (Fig. 3A). Correlating with the geology of the study area, the alteration zones of interest are observed at the northern and western parts of the study area. The massive high K-eTh ratio observed at the southern part of the study area (Hplb) is interpreted as 
felsic igneous rock as it generally has high K-eth ratio (Portnov, 1987; Hoover et al. 1992). Figure 3A clearly shows that the interpreted alteration zones are having NE-SW trend.

The eU-eTh ratio map (Fig. 3B) shows that the concentration of eTh is much higher than that of eU, as the ratios are less than 1. High eU-eTh ratio is observed at the western part of the study area which was interpreted to be characterized by pegmatite/quartz vein, while the low and moderate concentrations observed at the central and southern parts of the study area coincide with the presence of granite gneiss and some parts of schist zones in the northern part of the area. The eTh-eU ratio for normal continental crust is approximately 3.0, which shows that no significant fractionalisation occurred during weathering and there was no involvement of metasomatic activity of the radioelements (Okeyode et al. 2018).

It can be deduce from Hansen (1980) and Wollenberg and Smith (1987) that eU-K ratio for unaltered schist rock is about 1.14 ppm/\% and less than $0.76 \mathrm{ppm} / \%$ for granite. Altered schist rocks in the study area therefore have eU-K ratio less than $1.14 \mathrm{ppm} / \%$ and the schist rock zones in Figure 3C coincide with the altered zones mapped with the K-eTh ratio (Fig. 3A). Low eU-K ratio observed at the southern part (Hp1b) of the study area (Figure 3C) coincides with the granite zone and it is indicative of K enrichment in the granite rock. The Ternary map (Fig.3D) has high concentrations of eU, \% K and eTh depicted by the white colour in the Hp1a region and these are indication of felsic intrusions within the schist zones. The predominance of red colour at Hp1b region in the ternary map lends support to the presence of granite in the zone. The map (Fig. 3D) also shows that the formation, Mp1a, is dominated by Th with occasional intrusions of $\mathrm{U}$ and $\mathrm{K}$ in the schist formation. This suggests high content of quartzite and quartz within the rock unit. The imprint of $\mathrm{K}$ in the zone is an indication of hydrothermal alteration. Mp1b has high eTh concertation but moderate $\mathrm{K}$ concentration which suggests that the rock body has resulted from granitic gneiss whose thermal history could be responsible for the increase in its Th content. In the ternary map, Mp1b has recorded high concentrations of eTh and $\mathrm{U}$ with the Th content being slightly predominant. High concentrations of eTh and $\mathrm{eU}$ in the zone suggest that $\mathrm{Mp} 1 \mathrm{~b}$ could be migmatitic in nature.

\subsection{Summary of the deductions from the radio-isotope abundances and the ratios}

Tables 1, 2 and 3 summarise the results and the deductions made based on the concentration of each of the three radioactive elements in each region of the study area.

Table 1: Summary of the Results and the Deductions Made Based on the Potassium Concentration (\%) Grid of the Study Area

\begin{tabular}{lll}
\hline $\begin{array}{l}\text { Region on Concen- } \\
\text { tration Map }\end{array}$ & Concentration & Tentative Interpretation \\
\hline Hp1 & Very High & Porphyritic Granite \\
Hp2 & High (Moderate to high) & Gneiss with origin of felsic igneous rock \\
Mp1 & Moderate & Schist intruded by igneous rock \\
Lp1 & Low & Schist \\
Lp2 & Low & Schist \\
Lp3 & Low & Mafic to ultra-mafic rock unit \\
Lp4 & Low & Mafic to ultra-mafic rock unit \\
\hline
\end{tabular}

Table 2: Summary of the Results and the Deductions Made Based on the Thorium Concentration (ppm) Grid of the Study Area

\begin{tabular}{llll}
\hline $\begin{array}{l}\text { Region on Concentration } \\
\text { Map }\end{array}$ & Concentration & Tentative Interpretation & Interpretation \\
\hline Hp1a & Very High & Schist & Schist \\
Hp1b & Moderate to low & Porphyritic Granite & Porphyritic Granite \\
Hp2 & High to moderate & Metavolcanic rocks (Migmatite gneiss) & Metavolcanic rocks (Migmatite gneiss) \\
Mp1a & Moderate to low & Quartzo-feldspartic veins and quartzite rich & Quartzo-feldspartic veins and quartzite rich \\
Mp1b & schist & schist \\
Lp1 & Low & Granitic gneiss rock & Granitic gneiss rock \\
Lp2 & Qoderate to low & Quartzo-feldspartic veins and quartzite rich & Quartzite rich schist \\
Lp3 & schist & schist \\
Lp4 & Low & Mafic to ultra-mafic volcanic rock units & Mafic to ultra-mafic volcanic units \\
\hline
\end{tabular}

Table 3: Summarise of the Results and the Deductions Made Based on the Uranium Concentration (ppm) Grid of the Study Area

\begin{tabular}{llll}
\hline $\begin{array}{l}\text { Region on Concentration } \\
\text { Map }\end{array}$ & Concentration & Tentative Interpretation & Interpretation \\
\hline Hp1a & Very High & $\begin{array}{l}\text { Felsic and granitoid intrusions within the schist } \\
\text { (Schist) }\end{array}$ & $\begin{array}{l}\text { Felsic and granitoid intrusions within the schist } \\
\text { (Schist) }\end{array}$ \\
Hp1b & Moderate & Porphyritic Granite & Porphyritic Granite \\
Hp2 & High & Gneiss rock & Migmatite gneiss \\
Qp1a & Low & Quartzite rich altered schist & Migmatite gneiss \\
Mp1b & High & Gneiss rock & Quartzite rich schist \\
Lp1 & Low to moder- & Quartzite rich schist & Quartzite rich altered schist \\
Lp2 & ate & Quartzite rich altered schist & Mafic to ultra-mafic volcanic units \\
Lp3 & Low & Mafic to ultra-mafic volcanic units & Mafic to ultra-mafic volcanic units \\
Lp4 & Low & Mafic to ultra-mafic volcanic units &
\end{tabular}

\subsection{Proposed geologic map of the study area deduced from the airborne radiometric data}

From the analyses and interpretations drawn from all the maps, the proposed geological map of the study area deduced from the airborne radiometric data is presented in Figure 4. Five different kinds of formations were delineated; these are the schist, the meta-sediment quartzite rich schist, the porphyritic granites, mafic to ultramafic rocks and migmatite gneiss. The quartzite rich schist units recorded high radiometric activities for all the three radioactive elements, and the interpreted schists recorded relatively low activities of the three radioactive elements. 


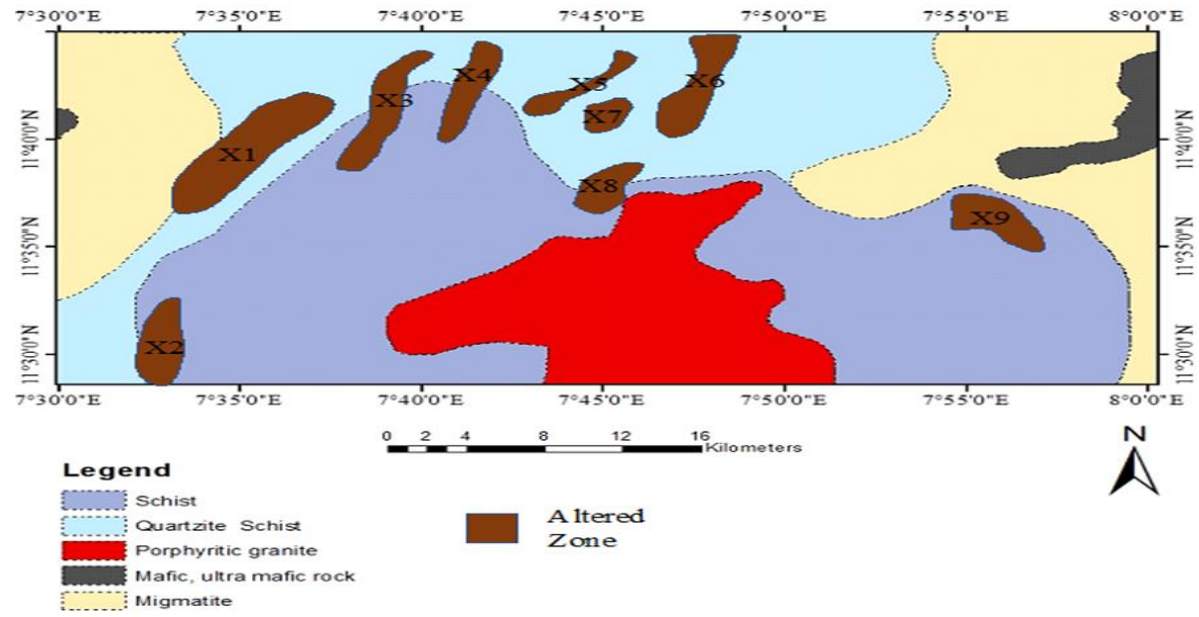

Fig. 4: Interpreted Geologic Map of the Study Area from Airborne Radiometric Data.

Hydrothermally altered zones were delineated as X1, X2, X4, X4, X5, X6, X7, X8 and X9. These zones are defined as zones with great potentials of hosting mineralization. The study area is known to be associated with gold mineralization; therefore, the altered zones have been identified to have great potentials to host gold mineralization, with $\mathrm{X} 1, \mathrm{X} 3, \mathrm{X} 4, \mathrm{X} 5, \mathrm{X} 6$ and $\mathrm{X} 7$ being the zones with greatest potentials.

\section{Conclusion}

The interpretation of the processed and enhanced radiometric data over Malumfashi Area, Northwestern Nigeria, led to the delineation of five geological formations, namely the schist, the meta-sediment quartzite rich schist, the porphyritic granites, mafic to ultramafic rocks and migmatite gneiss, in the area. These geologic formations predominantly have NE-SW trend. Hydrothermal alteration zones were mapped. These hydrothermally altered zones were noted to be associated with mineralization in the quartzite rich schist formations. The delineated geology and hydrothermally altered zones led to the identification of nine zones with the potentials of gold mineralization. The delineated structures aided the design of the geologic map of the study area.

\section{Acknowledgement}

We acknowledge the Nigerian Geological Survey Agency (NGSA) for the data used in this work.

\section{References}

[1] Abaa, S.I. (1983). The Structure and Petrography of Alkaline Rocks of the Mada Younger Granite Complex, Nigeria. Journal of African Earth Sciences, vol. 3, pp. 107-113. https://doi.org/10.1016/0899-5362(85)90029-6.

[2] Airo, M.L. (2002). Aeromagnetic and Aeroradiometric Response to Hydrothermal Alteration. Surveys in Geophysics, vol. 23 , pp. $273-302$. https://doi.org/10.1023/A:1015556614694.

[3] Black, R. (1980). Precambrian of West Africa. Episodes 4, pp. 3-8. https://doi.org/10.18814/epiiugs/1980/v3i4/001.

[4] Boadi, B. Wemegah, D.D. and Preko, K. (2013). Geological and Structural Interpretation of the Konongo area of the Ashanti Gold Belt of Ghana from Aeromagnetic and Radiometric Data. International Research Journal Geology and Mining (IRJGM) (2276-6618) vol. 3, no. 3, pp. 124-135.

[5] Boyle, R.W. (1979). The Geochemistry of Gold and its Deposits Together with a Chapter on Geochemical Prospecting for the Element. Geological Survey Canada, Bulletin 280, pp. 1 - 584. https://doi.org/10.4095/105577.

[6] Brempong, F., Wemegah, D., Preko, K., Armah, T., Boadi, B., Menyeh, A., Oppong, I., Quarshie, M., Aning, A., Asare, V. and Noye, R. (2019). Interpretation of Geological Structures Hosting Potential Gold Deposits in the Konongo Gold Mine Using Airborne Magnetic, Electromagnetic and Radiometric Datasets. Journal of Geoscience and Environment Protection, vol. 7, pp. 203-225. https://doi.org/10.4236/gep.2019.76016.

[7] Burke, K.C. and Dewey, J.F. (1972). Orogeny in Africa. In: T. F. J. Dessauvagie and A.J. Whiteman (eds), Africa geology, University of Ibadan Press, Ibadan Nigeria, pp. 583-608.

[8] Dada, S.S. (2006). Proterozoic evolution of Nigeria, In: O. Oshi (ed), The Basement Complex of Nigeria and its Mineral Resources. A Tribute to Prof. M. A. O. Rahaman, Akin Jinad \& Co. Ibadan, Nigeria, pp. 29-44.

[9] Dickson, B.L. and Scott, K.M. (1997). Interpretation of Aerial Gamma-Ray Surveys-Adding the Geochemical Factors. AGSO Journal of Australian Geology and Geophysics, vol. 17, pp. 187-200.

[10] Gandu, A.H., Ojo, S.B. and Ajakaiye, D.E. (1986). A Gravity Study of the Precambrian Rocks in the Malumfashi Area of Kaduna State, Nigeria. Tectonophysics vol. 126, pp. 181-194. https://doi.org/10.1016/0040-1951(86)90227-1.

[11] Garba, M.L. and Schoeneich, K. (2003). A Preliminary Report on the Hydrogeology of Kubanni Dam. Nigerian Journal of Scientific Research, vol. 4 , no. 1 , pp. $75-80$.

[12] Hansen, O.A. (1980). Radiometrics. In: Van blaricom, Richard, (ed) Practical Geophysics for the Exploration Geologist, pp. 1-38.

[13] Hoover, D.B. and Pierce, H.A. (1990). Annotated Bibliography of Gamma-Ray Methods Applied to Gold Exploration. U.S. Geological Survey Open-file Report 90-203, pp. 23. https://doi.org/10.3133/ofr90203.

[14] Hoover, D.B., Heran, W.D. and Hill, P.L. (1992). The Geophysical Expression of Selected Mineral Deposit Models. U.S. Geological Survey OpenFile report 92-557, pp. 129.

[15] Hore, P.N. (1970). Weather and Climate in Zaria and its Region. In: Mortimore. M. J. (ed.). Zaria and Its Region. Occasional Paper No. 4. Published by Department of Geography, Ahmadu Bello University, Zaria, Nigeria, pp. $41-54$.

[16] Ibe, S.O. (2016). Structures Favourable for Valley Formation in Basement Terrain. LAP LAMBERT Academic Publishing, Germany.

[17] Ibe, S.O., Egwuonwu, G.N. and Osazuwa, I.B. (2012). Delineation of All-Season-Charged Groundwater Reservoir from Two Valleys, Zaria Nigeria. Journal of Environmental Hydrology, vol. 20, no. 11, pp. 1 - 9.

[18] ICRU. (1994). Gamma ray Spectrometry in the Environment. ICRU Report 53. International Commission on Radiation Units And Measurements, Bethesda, USA 
[19] Kearey, P., Brooks, M. and Hill, I. (2006). An Introduction to Geophysical Exploration. Blackwell Scientific Publications. ELBS edition.

[20] Manu, J. (1993). Gold Deposits of Birimian Greenstone Belts in Ghana: Hydrothermal Alteration and Thermodynamics. Verlag Mainz, Wissenchaftsverlag, Aachen Herstellung: Fotodruck Mainz GmbH Susterfeldstr, 83. 52072 Aachen.

[21] Moxham, R.M. (1963). Natural Radioactivity in Washington Country, Maryland. Geophysics, vol. 28 , pp. $262-272$. https://doi.org/10.1190/1.1439174.

[22] Okeyode, I.C., Olurin, O.T., Ganiyu, S.A. and Olowofela, J.A. (2018). High Resolution Airborne Radiometric and Magnetic Studies of Ilesha and its Environs, Southwestern Nigeria. Original scientific paper, https://doi.org/10.2478/rmzmag-2018-0020.

[23] Onugba, A. (1979). Detailed Resistivity and Seismic Refraction Survey of Nasari/Kafur Kimberlite Pipe Area, Near Malumfashi Kaduna State. Unpublished M.Sc.Thesis. Physics Depertment., Ahmadu Bello University, Zaria, Nigeria.

[24] Olayinka, A.I. (1992). Geophysical Siting of Boreholes in Crystalline Basement Areas of Africa. Journal of African Earth Sciences, vol. 14, pp. 197-207. https://doi.org/10.1016/0899-5362(92)90097-V.

[25] Ostrovskiy, E.A. (1975). Antagonism of Radioactive Elements in Wellrock Alteration Fields and its use in Aerogamma Spectrometric Prospecting. International Geological Review, vol. 17, no. 4, pp. 461-468. https://doi.org/10.1080/00206817509471687.

[26] Portnov, A.M. (1987). Specialization of Rocks toward Potassium and Thorium in Relation to Mineralization. International Geological Review, vol. 29, pp. 326-344. https://doi.org/10.1080/00206818709466149.

[27] Rahaman, M.A. (1988). Recent Advances in Study of the Basement Complex of Nigeria Precambrian Geology of Nigeria. In: P. O. Oluyide, et al., (eds) Precambrian Geology of Nigeria, Geological Survey of Nigeria Publication, Kaduna, Nigeria, pp.11-43.

[28] Silva, A.M., Pires, A.C., McCafferty, A., Moraes, R. and Xia, H. (2003). Application of Airborne Geophysical Data to Mineral Exploration in the Uneven Exposed Terrains of the Rio Das Velhas Greenstone Belt. Revista Brasileira de Geociências, vol. 33, no. 2, pp. 17-28. https://doi.org/10.25249/0375-7536.200333S21728.

[29] Takyi-Kyeremeh, K., Wemegah, D.D., Preko, K. and Menyeh, A. (2019). Integrated Geophysical Study of the Subika Gold Deposit in the Sefwi Belt, Ghana. Cogent Geoscience, vol. 5, pp. 1-16. https://doi.org/10.1080/23312041.2019.1585406.

[30] Urquhart, W.E.S. (2013). Geophysical Airborne Survey: Radiometrics - Gamma-Ray Spectrometry. GeoExplo Ltda.

[31] Wollenberg, H.A. and Smith, A.R. (1987). Radiogenic Heat Production of Crustal Rocks - An Assessment Based on Geochemical Data. Geophysical Research Letters vol. 14, no. 3, pp. 295-298. https://doi.org/10.1029/GL014i003p00295. 